\title{
Pengaruh Kebijakan Lokal Terhadap Minat Melanjutkan Studi Perawat Di Lombok Timur Ke Jenjang Profesi S1 Keperawatan
}

\author{
Lalu Taufikurrahman $^{1)^{*}}$, Muksin $^{2)}$, Sarwadi $^{2)}$, Lalu M. Ismail $^{3)}$ \\ Email: taufikurrahmanlalu@outlook.com \\ 1) Mahasiswa S1 Keperawatan UNIQHBA \\ 2) Prodi Keperawatan UNIQHBA \\ 3) Prodi Rekam Medik dan Informasi Kesehatan UNIQHBA
}

\begin{abstract}
ABSTRAK
Keperawatan sebagai profesi dikembangkan sesuai dengan kemajuan ilmu pengetahuan dan teknologi (iptek) dan memperhatikan tuntutan kebutuhan masyarakat akan pelayanan kesehatan/keperawatan. Pemerintah Kabupaten Lombok Timur telah mengeluarkan kebijakan tentang Kompetensi Pegawai di lingkup Pemerintah Kabupaten Lombok Timur melalui pendidikan dan pelatihan. Salah satu bentuk program saat ini adalah pengembangan pegawai yang dilakukan melalui program pendidikan dan pelatihan kompetensi keperawatan professional. Tujuan dari penelitian ini adalah untuk mengetahui pengaruh dari kebijakan lokal terhadap minat melanjutkan studi keperawatan ke jenjang S1 keperawatan Lombok Timur tahun 2015. Penelitian ini merupakan penelitian deskriptif analitik yaitu dengan pengamatan langsung kelapangan. Populasi dalam penelitian ini adalah semua perawat yang ada di Kabupaten Lombok Timur (Puskesmas Sakra dan Puskesmas Lepak) sejumlah 45 perawat, sementara sampel dalam penelitian ini berjumlah 20 perawat. Dari hasil penelitian ini, responden yang berminat untuk melanjutkan studi sebesar (15\%), yang kurang berminat $(65 \%)$, dan yang tidak berminat sama sekali $(20 \%)$. Dukungan atasan terhadap minat melanjutkan studi sebesar $(60 \%)$, dan yang tidak mendukung sebesar $(40 \%)$.
\end{abstract}

Kata kunci: Kebijakan lokal, minat melanjutkan studi, profesi keperawatan.

\begin{abstract}
Nursing as a profession developed in accordance with the progress of science and technology (science) and pay attention to the demands of the health care needs of the community / nursing. East Lombok district government has issued a policy on the scope of the government's competence Employees in East Lombok through education and training. One form of the current program is the development of employees is done through educational programs and training of professional nursing competencies. The aim of this study was to determine the effect of local policies on the interest continue to pursue nursing studies nursing S1 East Lombok 2015. This study is a descriptive analytic research is the direct observation of spaciousness. The population in this study are all nurses in East Lombok (health centers and health centers Sakra Lepak) some 45 nurses, while the sample in this study amounted to 20 nurses. From these results, respondents who intend to continue the study of (15\%), are less interested (65\%), and who are not interested at all $(20 \%)$. Support superior to the interest of continuing studies $(60 \%)$, and which does not support amounting to $(40 \%)$.
\end{abstract}

Keywords: local policy, continued interest in the study, the nursing profession.

\section{A. LATAR BELAKANG}

Keperawatan sebagai profesi dikembangkan sesuai dengan kemajuan ilmu pengetahuan dan teknologi (iptek) dan memperhatikan tuntutan kebutuhan masyarakat akan pelayanan kesehatan/keperawatan. Pelayanan keperawatan yang berkualitas perlu didukung oleh sumber daya perawat yang dihasilkan dari institusi 
pendidikan yang berkualitas sesuai standar yang ditetapkan. Dengan demikian pendidikan perawat memegang peranan yang sangat penting dalam mewujudkan pelayanan yang berkualitas.

Pendidikan tinggi keperawatan merupakan bagian dari pendidikan nasional dengan pola pendidikan terdiri atas dua aspek yakni: pendidikan akademik dan pendidikan profesi. Kedua tahap pendidikan keperawatan ini harus diikuti karena keduanya merupakan tahapan pendidikan yang terintegrasi sehingga tidak dapat dipisahkan satu dengan yang lainnya.

Jumlah perawat menurut data Persatuan Perawat Nasional Indonesia (PPNI) mencapai sekitar $60 \%$ dari total tenaga kesehatan yang ada di Indonesia. Selain jumlahnya dominan, keperawatan adalah profesi yang berperan penting dalam upaya menjaga mutu pelayanan kesehatan baik itu rumah sakit, puskesmas dan klinik kesehatan. Dari hasil survai Departemen Kesehatan tahun 2005, menunjukkan bahwa tenaga kesehatan diseluruh Indonesia khususnya perawat yaitu sekitar 211.422 orang tenaga perawat dari 769.832 orang tenaga kesehatan di seluruh Indonesia. Sedangkan untuk tahun 2013 di rencanakan seluruh tenaga kesehatan 1.305.000 orang tenaga kesehatan dan 355.411 orang tenaga perawat profesional yang dibutuhkan. Secara keseluruhan tampaknya jumlah pengembangan dan penyediaan tenaga kesehatan pada tahun 2015 cukup seimbang. Akan tetapi, bila ditinjau secara lebih spesifik pengembangan untuk kategori tenaga kesehatan profesional masih kurang mencukupi yaitu salah satunya tenaga perawat [1].

Menurut data dari Dirjen Bina Upaya Kesehatan (BUK) berdasarkan Sistem Informasi Rumah Sakit, sebagian besar atau $80 \%$ perawat yang bekerja di rumah sakit berpendidikan Diploma III, Diploma IV 0,5\%, Sarjana (S1keperawatan) $1 \%$, Ners 1\%, dan S2 0,4\%. Sedangkan yang berpendidikan SPK sebanyak 7\%. Hal ini belum sesuai dengan standar profesi[2].

Perawat profesional merupakan perawat lulusan perguruan tinggi pada jenjang sarjana, bagi perawat lulusan D-III Keperawatan masih disebut sebagai perawat vokasional atau profesional pemula. Salah satu indikator makro perawat profesional adalah minimal berpendidikan sarjana yang ditempuh melalui dua tahap pendidikan: tahap akademik 8 semester untuk lulusan SMA, dan 3 semester untuk lulusan DIII Keperawatan dan tahap praktik profesi Ners 2 semester.

Keluarnya Undang-Undang Nomor 23 Tahun 1992 tentang Kesehatan yang kemudian diamandemen dengan Undang-Undang Nomor 36 Tahun 2009, tentang Kesehatan, UndangUndang Nomor 20 Tahun 2003 tentang Sistem Pendidikan Nasional, Peraturan Pemerintah Nomor 32 Tahun 2001 tentang Tenaga Kesehatan, Keputusan Menteri kesehatan RI Nomor 1239 tahun 2001 tentang Registrasi dan Praktik Perawat, Peraturan Menteri Kesehatan RI Nomor 148 Tahun 2010 tentang Izin dan Penyelenggaraan Praktik Perawat, serta Peraturan Menteri Kesehatan RI Nomor 1796 Tahun 2011 tentang Registrasi Tenaga Kesehatan, lebih mengukuhkan perawat sebagai suatu profesi di Indonesia. Dikeluarkannya Peraturan Menteri Kesehatan Nomor 148 Tahun 2010 tentang Izin dan Penyelenggaraan Praktik Perawat serta Undang-Undang Terbaru No. 38 tahun 2014 tentang Keperawatan tersebut lebih menjelaskan lagi batasan kewenangan profesi perawat, sehingga perawat mempunyai legitimasi dalam menjalankan praktik profesinya[3].

Beranjak dari Peraturan Pemerintah dan Permenkes tersebut, pemerintah Kabupaten Lombok Timur telah mengeluarkan kebijakan tentang Kompetensi Pegawai di lingkup Pemerintah Kabupaten Lombok Timur melalui pendidikan dan pelatihan. Salah satu bentuk program saat ini adalah pengembangan pegawai yang dilakukan melalui program pendidikan dan pelatihan kompetensi keperawatan profesional. Kabupaten Lombok Timur sendiri adalah salah satu dari 10 Kabupaten/kota yang ada di Provinsi Nusa Tenggara Barat dengan luas wilayah $2,679,99 \mathrm{~km}^{2}$ yang terdiri dari daratan dan lautan, 
dengan jumlah penduduk 1,130,365. Jumlah tenaga medis 1,865 orang yang terdiri dari tenaga keperawatan sebanyak 860 orang, bidan 670 orang dan sisanya dari Dokter dan tenaga medis lainnya. Dimana tenaga keperawatan sebagian besar masih berpendidikan DIII sebanyak 450 orang atau $53.3 \%$, tenaga keperawatan dengan kualifikasi S1 atau Sarjana keperawatan sebanyak 225 orang atau $26,2 \%$, dan SPK sebanyak 205 orang atau 23,8\%[4].

Untuk meningkatkan kompetensi tersebut, Pemerintah Kabupaten Lombok Timur menerbitkan surat keterangan izin belajar yang di tanda tangani oleh Bupati dengan ketentuan 1) perkuliahan dilaksanakan sore hari (diluar jam kerja), 2) tidak mengganggu tugas kedinasan, 3) biaya pendidikan ditanggung sendiri oleh yang bersangkutan, tidak menuntut biaya dan kenaikan pangkat penyesuaian ijazah serta tuntutan lainnya dari Pemerintah Kabupaten Lombok Timur, 4) setelah selesai mengikuti pendidikan, yang bersangkutan diharuskan melapor kepada Sekretaris Daerah melalui Kepala badan Kepegawaian dan Diklat Kabupaten Lombok Timur.

Dari data di atas dapat dilihat bahwa pengembangan karier perawat di Kabupaten Lombok Timur masih kurang. Hal ini dibuktikan oleh masih banyak yang memiliki kualifikasi pendidikan DIII Keperawatan yaitu 53.3\%, kualifikasi pendidikan ini diharapkan dapat dikembangkan atau ditingkatkan ke S1 Keperawatan (ners) dan pada akhirnya dapat memenuhi tuntutan masyarakat akan pelayanan perawatan yang profesional. Berdasarkan hasil wawancara dari 10 orang perawat di salah satu Puskesmas yang ada di Lombok Timur yang terdiri dari 8 orang perawat yang berpendidikan D III keperawatan mengatakan bahwa faktor jenis kelamin, usia, status perkawinan, pendapatan serta dukungan atasan yang menyebabkan kurangnya motivasi untuk melanjutkan pendidikan. Serta 2 orang perawat yang berpendidikan SPK mengatakan bahwa faktor usia, waktu dan kesempatan yang menyebabkan kurangnya motivasi untuk melanjutkan pendidikan[4].

\section{B. METODE PENELITIAN}

Penelitian ini merupakan penelitian deskriptif analitik yaitu dengan pengamatan langsung ke lapangan.

\section{Lokasi dan Waktu Penelitian}

Penelitian ini dilakukan di Puskesmas Sakra dan Puskesmas Sakra Timur. Penelitian ini dilaksanakan pada 2015.

\section{Populasi dan Sampel}

Populasi dalam penelitian ini adalah semua perawat yang ada di Kabupaten Lombok Timur (Puskesmas Sakra dan Puskesmas Sakra Timur) sejumlah 45 perawat. Sampel dalam penelitian ini adalah semua perawat yang ada di Kecamatan Sakra dan Kecamatan Sakra Timur yang berjumlah 20 perawat.

\section{Data Penelitian}

Data primer yaitu data yang bersumber langsung dari responden, yaitu seberapa besar minat perawat untuk melanjutkan studi ke jenjang S1. Data sekunder yaitu data yang berupa data dokumen-dokumen seperti data mengenai keadaan demografi suatu daerah, data mengenai keadaan seseorang. Dalam penelitian ini yang termasuk data sekunder adalah data tentang gambaran umum lokasi tempat penelitian yaitu puskesmas Sakra dan puskesmas Lepak Kabupaten Lombok Timur.

\section{Instrumen dan Pengolahan Data}

Data Primer yang meliputi minat dan kebijakan lokal di ambil dengan cara wawancara menggunakan alat bantu kuisioner. Pengambilan data sekunder dengan cara melihat dokumendokumen yang berkaitan dengan lokasi tempat penelitian yaitu puskesmas Sakra dan puskesmas Lepak Kabupaten Lombok Timur. Kuesioner diisi berdasarkan jawaban wawancara responden. Pertanyaan menggunakan kuesioner menyangkut pengaruh kebijakan lokal terhadap minat melanjutkan studi perawat dibuat dalam bentuk pilihan, apabila jawaban benar diberi nilai 1 apabila jawaban salah diberi nilai 0 .

Pengolahan data dilakukan dengan cara analisis bivariat adalah analisis terhadap dua 
variabel dengan tujuan mencari pengaruh antara kedua variabel tersebut. Dalam penelitian ini hubungan antara variable diolah menggunakan uji korelasi Product Moment karena kedua variabel merupakan jenis variabel kategori dengan skala ordinal, dan dianalisis dengan menggunakan bantuan program SPSS versi 17.0 for windows[5].

\section{HASIL DAN PEMBAHASAN}

1. Minat Perawat Untuk Melanjutkan Studi

Kategori minat perawat dalam penelitian ini dikelompokkan menjadi 3 kategori, yaitu: berminat, kurang berminat dan tidak berminat.

Tabel 1. Minat Perawat untuk Melanjutkan Studi

\begin{tabular}{|c|c|c|c|}
\hline No & Kategori & $\begin{array}{c}\text { Frekuensi } \\
\text { (orang) }\end{array}$ & $\begin{array}{c}\text { Persentase } \\
(\%)\end{array}$ \\
\hline 1 & Berminat & 3 & 15 \\
\hline 2 & $\begin{array}{c}\text { Kurang } \\
\text { berminat }\end{array}$ & 13 & 65 \\
\hline 3 & $\begin{array}{c}\text { Tidak } \\
\text { berminat }\end{array}$ & 4 & 20 \\
\hline \multicolumn{2}{|r|}{ Total } & 20 & 100 \\
\hline
\end{tabular}

Dari hasil analisis kuesioner yang ditampilkan pada Tabel 1. didapat bahwa responden yang berminat sebanyak 3 responden (15\%), yang kurang berminat sebanyak 13 responden $(65 \%)$, dan yang tidak berminat sama sekali sebanyak 4 responden (20\%).

Tabel 2. Distribusi Responden Berdasarkan Golongan Usia

\begin{tabular}{|c|c|c|c|}
\hline No & Usia (tahun) & $\begin{array}{c}\text { Frekuensi } \\
\text { (orang) }\end{array}$ & $\begin{array}{c}\text { Persentase } \\
(\%)\end{array}$ \\
\hline 1 & $20-40$ & 13 & 65 \\
\hline 2 & $>40$ & 7 & 35 \\
\hline \multicolumn{2}{|c|}{ Total } & 20 & 100 \\
\hline
\end{tabular}

Tabel 2. memperlihatkan bahwa responden yang diteliti dikategorikan pada dua kelompok usia yaitu usia 20-40 tahun dan lebih dari 40 tahun. Usia 20-40 tahun yang mendominasi perawat tergolong dewasa muda sebanyak $65 \%$ sedangkan yang berusia lebih dari 40 tahun sebanyak $35 \%$.

Pengolahan data menunjukkan ada pengaruh antara usia perawat dengan minat melanjutkan pendidikan kejenjang sarjana dengan nilai $\mathrm{p}=$ 0,084 yang artinya ada pengaruh antara usia perawat dengan minat melanjutkan studi ke jenjang sarjana keperawatan.

Faktor dorongan dari dalam, faktor dorongan yang bersifat sosial dan faktor yang berhubungan dengan emosional memengaruhi minat melanjutkan studi. Faktor dari dalam dapat berupa kebutuhan yang berhubungan dengan jasmani dan kejiwaan. Timbulnya minat dari diri seseorang juga dapat didorong oleh adanya motivasi sosial yaitu mendapatkan pengakuan dan penghargaan dari lingkungan masyarakat dimana seseorang berada, sedangkan faktor emosional memperlihatkan ukuran intensitas seseorang dalam menanam perhatian terhadap suatu kegiatan atau obyek tertentu.

\section{Dukungan Atasan/Kebijakan Lokal}

Dukungan atasan dikelompokkan menjadi 2 kategori, yaitu: mendukung dan tidak mendukung.

Tabel 3. Dukungan Atasan Terhadap Minat Perawat untuk Melanjutkan Studi

\begin{tabular}{|c|c|c|c|}
\hline No & Kategori & $\begin{array}{c}\text { Frekuensi } \\
\text { (orang) }\end{array}$ & $\begin{array}{c}\text { Persentase } \\
(\%)\end{array}$ \\
\hline 1 & Mendukung & 3 & 60 \\
\hline 2 & $\begin{array}{c}\text { Tidak } \\
\text { mendukung }\end{array}$ & 2 & 40 \\
\hline \multicolumn{2}{|c|}{ Total } & 5 & 100 \\
\hline
\end{tabular}

Dari hasil analisis kuesioner yang ditampilkan pada Tabel 3. didapat bahwa dukungan atasan terhadap minat melanjutkan studi sebesar $60 \%$, dan tidak mendukung sebesar $40 \%$.

Berdasarkan perhitungan dengan rumus korelasi product moment didapat nilai $\mathrm{rxy}=0,84$ dan nilai $\mathrm{p}$-value $=0,800$, pengaruh minat dan nilai $r x y=0,84$ dan nilai $p$-value $=0,800$ untuk pengaruh kebijakan lokal, artinya terdapat pengaruh kebijakan lokal terhadap minat melanjutkan studi perawat di Lombok Timur ke jenjang profesi S1 keperawatan. Hubungan yang ditunjukkan sangat kuat.

Dukungan atasan sangat penting untuk diterima, karena dukungan atasan dapat diartikan sebagai sebuah reward yang positif bagi bawahan karena bisa juga diartikan sebagai sebuah promosi yang harus diterima bawahan, dengan 
adanya dukungan atasan, secara langsung akan dirasakan menjadi sebuah motivasi untuk meraih sesuatu, seperti melanjutkan pendidikan kejenjang sarjana misalnya. Dukungan atasan menjadi sebuah semangat dan tanggung jawab bawahan untuk membuktikan bahwa dirinya mampu melaksanakan dukungan tersebut.

\section{KESIMPULAN}

Berdasarkan hasil penelitian dan pembahasan yang telah dikemukakan maka disimpulkan bahwa minat perawat untuk melanjutkan studi ke jenjang sarjana sangat tinggi hubungannya dengan kebijakan pemerintah di Kabupaten Lombok Timur. Hal ini juga tidak terlepas dari factor usia perawat yang berkorelasi positif.

\section{DAFTAR PUSTAKA}

[1] Pusat Data Informasi Kementerian Kesehatan Republik Indonesia. 2017. Infodatin $12 \mathrm{Mei}$ Situasi Keperawatan Indonesia. Jakarta Selatan: Kemenkes RI.

[2] Dirjen Bina Daya Kesehatan. 2005. Sistem Informasi Kesehatan Rumah Sakit, (online) http://sirs.yankes.kemkes.go.id/sirs.

[3] Undang-Undang Republik Indonesia No. 38 Tahun 2014 Tentang Keperawatan

[4] Dinas Kesehatan Lombok Timur. 2015. Profil Kesehatan Kabupaten Lombok Timur. Selong: Pemkab Lombok Timur.

[5] Notoatmodjo, S. 2005. Metodologi Penelitian Kesehatan. Jakarta: Rineka Cipta. 